\title{
Scale-up thermostable $\alpha$-amylase production in lab-scale fermenter using rice husk as an elicitor by Bacillus licheniformis-AZ2 isolated from Qinarje Hot Spring (Ardebil Prov. of Iran)
}

\author{
ALI DELJOU ${ }^{1}$ \\ IMAN AREZI ${ }^{2, *}$ \\ MORTEZA KHANAHMADI ${ }^{2}$ \\ ${ }^{1}$ College of Agricultural Science, Department of \\ Agricultural Biotechnology, Bu-Ali Sina University, \\ Hamedan, Iran. \\ 2 Branch of Central Region (Isfahan), Agricultural \\ Biotechnology Research Institute of Iran (ABRII), \\ Isfahan, Iran. \\ *Correspondence: \\ Iman Arezi \\ E-mail: iman.arezi@yahoo.com
}

List of nonstandard abbreviations: 16S rRNA: 16 S ribosomal RNA Agro-wastes: Agricultural- wastes ANOVA: Analysis of Variance CRD: Completely Randomized Design DNS Reagent: 3,5- di nitro salicylic acid reagent LB medium: Luria-Bertani medium OFAT method: one-factor-at-a-time method rpm: Revolutions per minute SmF: Submerged fermentation SSF: Solid state fermentation STR: Stirred Tank Reactor vvm: Volume of air per unit volume of liquid medium per minute

Keywords: Bacillus licheniformis; Agro-waste; Thermostable $\alpha$-amylase; Scale-up; Aeration; Agitation; Shake flask; Stirred tank fermenter.

Received April 17, 2018

Revised May 17, 2018

Accepted May 18, 2018.

\begin{abstract}
:
Background and purpose: Amylases are commercially important enzymes with various biotechnological, clinical and medical applications. This study aimed at scaling up $\alpha$-amylase production elicited by rice husk in stirred-fermenter using Bacillus lichneniformis- $A Z 2$ isolated from Qinarje Hot Spring.
\end{abstract}

Materials and methods: Effect of temperature, aeration rate and agitation speed on bacterial growth and $\alpha$-amylase production were investigated under batch fermentation process in a 3-Lit stirred-fermenter. OFAT method was followed to select optimum level of each parameter. Other factors were set upon the results of previous experiments carried out in shake-flask scale.

Results: Maximum $\alpha$-amylase production of $17.66 \pm 0.87 \mathrm{U} / \mathrm{mL}$ (2.1 folds more than shake-flask cultures) was achieved in stirred-fermenter with optimized agitation speed of $100 \mathrm{rpm}$ and $1 \mathrm{vvm}$ aeration rate at $37^{\circ} \mathrm{C}$ after $60 \mathrm{~h}$ of incubation. This time was shorter than the corresponding fermentation time obtained from shake-flask experiments by half. A comparison of kinetic parameters offermentation in stirred-fermenter and shakeflask cultures revealed that $B$. licheniformis- $A Z 2$ was more active to synthesize $\alpha$-amylase in fermenter. In shaken cultures $Q_{x}, Q_{p}, Y_{p / x}, \mu m a x, q_{p}$ and $t$, were $0.27(\mathrm{~g} / \mathrm{L} / \mathrm{h}), 228.6(\mathrm{U} / \mathrm{L} / \mathrm{h}), 13.64(\mathrm{U} / \mathrm{g}), 0.055\left(\mathrm{~h}^{-1}\right), 0.76(\mathrm{U} / \mathrm{g} / \mathrm{h})$ and $12.48 \mathrm{~h}$, whereas in stirred-fermenter the above values were 0.40 $(\mathrm{g} / \mathrm{L} / \mathrm{h}), 723.1(\mathrm{U} / \mathrm{L} / \mathrm{h}), 45.17(\mathrm{U} / \mathrm{g}), 0.120\left(\mathrm{~h}^{-1}\right), 5.42(\mathrm{U} / \mathrm{g} / \mathrm{h})$ and $5.78 \mathrm{~h}$, respectively.

Conclusions: SmF in stirred-fermenter is a potential strategy for $\alpha$ amylase production. Although for commercialization further studies are needed in pilot-scale. Rice husk as a low-cost agro-waste is preferable to use as the carbon and energy sources for maximum $\alpha$-amylase production.

\section{INTRODUCTION}

Towadays industrially important enzymes are mainly produced by 1 thermophilic microorganisms originated from different geothermal environments such as Hot Springs and marine hydrothermal vents $(1,2)$. Thermophilic microorganisms are able to live with optimal temperature ranges from $40^{\circ} \mathrm{C}$ to $80^{\circ} \mathrm{C}$ (3). Due to the optimal activity and 
stability of the released enzymes by extremophiles under extreme conditions, new catalytic alternatives for current industrial applications have recently been offered by extremozymes (4).

Among the various industrial enzymes, amylases (i.e. $\alpha$-amylases, $\beta$-amylases and glucoamylases) rank first in terms of their commercial exploitation, so approximately that they share $25-33 \%$ of the world enzyme market (5-7). $\alpha$-amylases (E.C. 3.2.1.1.) are extra-cellular, endo starch-degrading enzymes which catalyze breaking down the internal $\alpha-1,4-O$-glycosidic bonds in starch to low molecular weight products, such as glucose, maltose and maltotriose units with the retention of $\alpha$-anomeric configuration in them (8).

$\alpha$-amylases have a wide variety of applications in starch processing, food, animal feed, baking, alcohol fermentation, detergent, textile and paper industries (9). They also have promising applications in medical, clinical and molecular biology fields as well $(5,10)$. Industrial production of this enzyme is mainly carried out in submerged mode of fermentation using different types of microorganisms such as bacteria, fungi, yeasts, and actinomycetes $(11,12)$. However, enzymes derived from fungal and bacterial sources are more favored for industrial applications (13). Among them, bacterial $\alpha$-amylases due to the advantages and several characteristics that they offer are more preferred over fungal amylases (14).

Bacilli are used as bacterial workhorses in industrial microbial cultivations for the production of a variety of enzymes (15). It is estimated that Bacillus sp. enzymes comprise about $50-60 \%$ of the total global enzyme market (5). B. subtilis, B. stearothermophilus, B. licheniformis and $B$. amyloliquifaciens are known as the best $\alpha$-amylase producers among Bacillus species (12). Although the production of bacterial $\alpha$-amylases has been thoroughly studied in submerged fermentation $(\mathrm{SmF})$ and solid state fermentation (SSF), because of the greater control on environmental factors such as temperature, $\mathrm{pH}$, etc. and ease of handling, $\mathrm{SmF}$ is more common $(13,16)$.

In general, bioprocess development is categorized in three main scales i.e. laboratory scale, pilot plant and production plant, which shake-flask scale also can be added to this list (17). One of the major concerns that researchers were faced with, was to find a way in order to facilitate scaling up the submerged fermentations from shake flask level to production scale (18). Bioreactors (also known as fermenters) are regarded as the heart of the fermentation process, which greatly have helped overcome this issue (19). Bioprocess scale-up involves a series of stages, these stages are flask level (50-1000 g working capacity), laboratory level (2-20 kg working capacity), pilot level (50$5000 \mathrm{~kg}$ working capacity) and production level (255000 tons working capacity) (17).
The scale-up of microbial product formation from a shake flask to a fermenter comprises optimization of culture conditions in fermentation processes (20). So far, stirred-tank reactors (STRs) have been the most common fermenters used at the laboratory scale for studying SmF. The major preferences of this kind of fermenter over the rest are their homogenous system, excellent mixing and reasonably good heat and mass transfer rates, ease of handling and cleaning, compatibility with different operational patterns like batch, fed-batch, continuous, cell recycle and greater control over important factors, such as temperature, $\mathrm{pH}$, air supply, rpm, and foam (21). The secretion of microbial enzymes in fermentation process is dependent on several factors, such as composition of the fermentation medium, carbon and nitrogen sources, mineral salts, trace elements, type of strain, and also fermentation conditions i.e. $\mathrm{pH}$, temperature, dissolved oxygen concentration, agitation etc. $(22,23)$.

In stirred tank bioreactors aeration and agitation are two vital operational parameters, which play important role in scale-up of aerobic biosynthesis systems and industrial bioprocess development (24). In aerobic fermentation, oxygen has an influence on enzyme secretion and this might be because of metabolic activities in the organism (25). It has been recognized that amylase production by many Bacillus spp. is affected by the amount of dissolved oxygen. Therefore, forced aeration of the fermentation medium could be promising as it offers higher efficiency by combining aeration with agitation (26).

In our previous study we screened several potent $\alpha$ amylase producing bacteria isolated from Qinarje Hot Spring water sample, and found that B. licheniformis-AZ2 gives superior $\alpha$-amylase activity. Then by implementing OFAT design $\alpha$-amylase production was enhanced 2.4 folds in optimized fermentation medium compared to the basal medium. In addition, stability of the partially purified enzyme over a broad range of $\mathrm{pH}(6.0$ to 10.0) and temperature $\left(30^{\circ} \mathrm{C}\right.$ to $\left.80^{\circ} \mathrm{C}\right)$ in the presence of $\mathrm{CaCl}_{2}$ implied that the produced calcium dependent enzyme could be categorized as alkaliphilic-thermostable $\alpha$-amylases (27). The present study intends to investigate the effect of incubation temperature, aeration rate and agitation speed on $\alpha$-amylase production by $B$. licheniformisAZ2 under Lab-scale fermenter in comparison with optimal conditions in shake flask.

\section{MATERIALS AND METHODS}

\section{Chemicals and reagents}

The DNS reagent and silicon antifoam reagent were prepared from Sigma-Aldrich (USA). Tryptone, peptone, tryptophan and bacteriological agar powder from HiMedia (India) were also used for experiments. All other chemicals were purchased from Merck (Germany). 


\section{Microorganism}

The strain B. licheniformis-AZ2 used in the present study was obtained from Microbial Collection of Agricultural Biotechnology Department, at Bu-Ali Sina University, Hamedan, Iran. This strain has recently been isolated from Qinarje Hot Spring's water sample $\left(82^{\circ} \mathrm{C}\right.$ and $\mathrm{pH}$ 6.5) and identified based on $16 \mathrm{~S}$ rRNA gene sequence method (GenBank: KT281607.1; https://www.ncbi.nlm. nih.gov/nuccore/893670518).

\section{Inoculum development of B. licheniformis-AZ2}

The strain of B. licheniformis-AZ2 was streaked on LB agar plate and incubated for $24 \mathrm{~h}$ at $40^{\circ} \mathrm{C}$. Then, a loopfull of freshly grown bacterial cells were transferred into $100 \mathrm{~mL}$ of LB liquid medium [tryptone $10, \mathrm{NaCl} 10$ and yeast extract $5(\mathrm{~g} / \mathrm{L})]$ and incubated at $40^{\circ} \mathrm{C}$. Inoculum was taken from the early exponential phase of growth after $24 \mathrm{~h}$.

\section{$\alpha$-Amylase production in shake flask}

$\alpha$-amylase production under submerged fermentation $(\mathrm{SmF})$ condition was carried out in $250 \mathrm{~mL}$ Erlenmeyer flasks by taking $100 \mathrm{~mL}$ of optimized fermentation medium consisting of $(\mathrm{g} / \mathrm{L})$ : rice husk 10 , tryptone 10 , tryptopohan $1, \mathrm{CaCl}_{2} 0.3$ and $2 \%(\mathrm{w} / \mathrm{v})$ of Tween $80(\mathrm{pH} 9.0)$. The aliquot of $2 \%(\mathrm{v} / \mathrm{v})$ of the total optimized medium was taken as inoculum. After inoculation, the culture flask of $S \mathrm{mF}$ was carried out using the optimum growth conditions at $40^{\circ} \mathrm{C}$ on a rotary shaker at $120 \mathrm{rpm}$ for 144 $\mathrm{h}$. This fermentation medium was previously optimized on a shake-flask scale using OFAT method for enhanced production of $\alpha$-amylase by B. licheniformis-AZ2 (27). The stimulatory effect of tryptophan was confirmed in complementary studies (Unpublished data).

\section{a-Amylase production in stirred fermenter}

Fermenter studies were carried out in a 3-L glass fermenter with a working volume of $1 \mathrm{~L}$ (Designed and constructed at Bu-Ali Sina University, Department of Agricultural Biotechnology). The fermentation medium was the same with shake flask culture. Agitation was performed using a flat-blade turbine impeller. The aeration system was an air filtered sterile (Membrane filter, 0.22 $\mu \mathrm{m}$ pore size) inlet through a ring sparger with portable air-flow meter. The $\mathrm{pH}$ of optimized fermentation medium was adjusted at 9.0 with $0.1 \mathrm{~N} \mathrm{HCl} / \mathrm{NaOH}$ before sterilization at $15 \mathrm{lbs} / \mathrm{in}^{2}$ pressure $\left(121^{\circ} \mathrm{C}\right)$ for $20 \mathrm{~min}$ (Reyhan Teb, F2000, Iran). Foam was suppressed, when necessary, by the addition of sterilized silicon antifoam reagent $(10 \mathrm{v} / \mathrm{v})$. The $\mathrm{pH}$ was kept constant at 9.0 using sterilized solution of $0.1 \mathrm{~N} \mathrm{HCl} / \mathrm{NaOH}$ during entire fermentation process. The inoculated fermenter was incubated at $37^{\circ} \mathrm{C}$ for $96 \mathrm{~h}$.

\section{Optimization of cultural conditions in stirred fermenter}

Experiments for optimization of the cultural conditions i.e. incubation temperature, agitation speed and aeration rate were conducted using OFAT methodology, the best choice in each experiment was used for the optimization of the next factor.

\section{Incubation temperature}

To study the effect of incubation temperature on $\alpha$ amylase production and cell growth, the fermentation was carried out at different temperatures $\left(30^{\circ} \mathrm{C}, 35^{\circ} \mathrm{C}, 37^{\circ} \mathrm{C}\right.$, $40^{\circ} \mathrm{C}, 45^{\circ} \mathrm{C}$ and $50^{\circ} \mathrm{C}$ ) with constant aeration rate of 0.5 vvm and agitation speed of $100 \mathrm{rpm}$.

\section{Aeration rate}

The production of $\alpha$-amylase was studied at aeration rates of $0,0.5,1.0,1.5,2.0$ and $2.5 \mathrm{vvm}$. During the fermentation, the agitation speed of the impeller was kept at $100 \mathrm{rpm}$ and optimal temperature of $37^{\circ} \mathrm{C}$.

\section{Agitation speed}

Different agitation speeds of 50,100,150, 200, 250 and $300 \mathrm{rpm}$ with optimal aeration rate of $1 \mathrm{vvm}$ and incubation temperature of $37^{\circ} \mathrm{C}$ were investigated for optimum $\alpha$-amylase production.

\section{Statistical analysis}

All experiments were carried out in three replications based on a completely randomized design (CRD). Mean values and standard errors were calculated from the average results of three fermenter runs for each process parameter. Statistical analysis was performed using SPSS V 16.0 software (SPSS Inc. Polar Engineering and Consulting, USA) based on single factor analysis of variance (ANOVA). Duncan's multiple range test was used for mean comparison of the treatments at a $p$ value of 0.05 .

\section{Analytical methods}

\section{Determination of biomass}

At regular intervals $(6 \mathrm{~h})$ samples from the fermenter and shake flasks were drawn. The total cell concentration was estimated by measuring optical density of fermented broth at $600 \mathrm{~nm}$, and the obtained values were converted to cell dry weight $(\mathrm{mg} / \mathrm{mL})$ using a calibration curve. The cells were collected by centrifugation $(10,000 \times \mathrm{g}$ for 10 $\min$ at $4^{\circ} \mathrm{C}$ ) in a refrigerated centrifuge (Eppendorf 5810R, Germany) and the cell free supernatant was analyzed for reducing sugar and enzyme activity.

\section{Assay of $\alpha$-amylase}

$\alpha$-amylase activity was determined by spectrophotometric method as described by Rick and Stegbauer (28). 


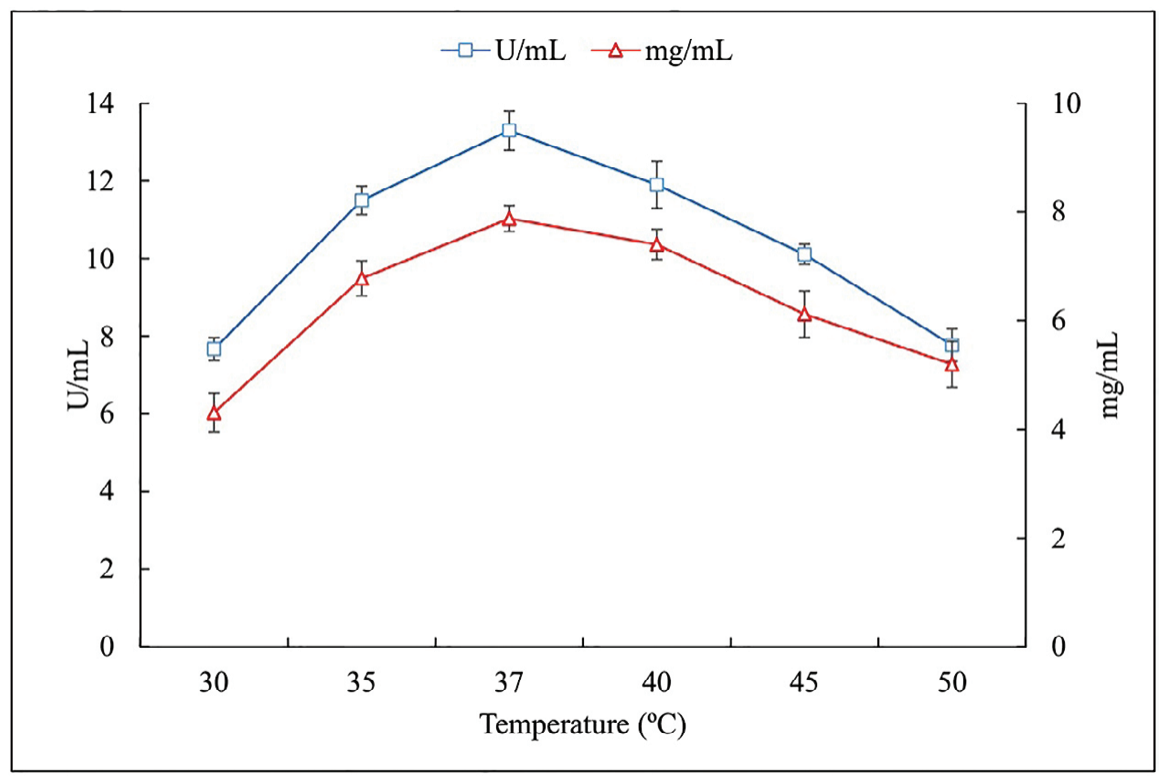

Figure 1. Effect of temperature on cell growth and production of $\alpha$-amylase by B. licheniformis- $A Z 2$ at $p H 9.0$, aeration rate of 0.5 vvm and agitation speed of $100 \mathrm{rpm}$ after $60 \mathrm{~h}$.

Mean \pm S.E.M $=$ Mean values \pm Standard error of means of three replications.

According to the procedure $\alpha$-amylase activity was assayed by adding $1 \mathrm{~mL}$ of enzyme (crude extract/fermented broth cell- free supernatant) to $1 \mathrm{~mL}$ of $1 \%(\mathrm{w} / \mathrm{v})$ soluble starch in $50 \mathrm{mM}$ Tris- $\mathrm{HCl}$ buffer $(\mathrm{pH}=7.0)$ in a test tube. The test tubes covered and incubated for $5 \mathrm{~min}$ at $80^{\circ} \mathrm{C}$ in a water bath. Then $2 \mathrm{~mL}$ DNS reagent was added to each tube to stop the reaction and placed in boiling water bath exactly for $5 \mathrm{~min}$. After cooling the samples in a cold water bath, the absorbance was read at $540 \mathrm{~nm}$ by spectrophotometer (Varian CARY 100 UV-VIS, Australia). An $\alpha$-amylase activity unit was defined according to the amount of $\alpha$-amylase required to catalyze the liberation of reducing sugar equivalent to one $\mu$ mole of maltose per minute under the assay conditions.

\section{Kinetic analysis}

Fermentation kinetic parameters were determined according to the methods described by Pirt (29) and Lawford and Rouseau (30):

- $\mu_{\max }$ was estimated as steepest slope of natural $\log (\ln$ $\mathrm{X}$ ) of biomass against time (h) of fermentation.

- $t_{d}$ was calculated from $\mu_{\max }$ by use of the following equation:

$$
\text { (1) } t_{d}=0.693 / \mu_{\max }
$$

- $\mathrm{Q}_{\mathrm{x}}$ ( $\mathrm{g}$ cell mass $/ \mathrm{L} / \mathrm{h}$ ) was calculated as highest slope of cell mass vs. time curve.

- $\mathrm{Q}_{\mathrm{p}}(\mathrm{U} / \mathrm{L} / \mathrm{h})$ was estimated as maximum slope of culture medium's alpha amylase activity vs. time during the course of fermentation.
- $\left(\mathrm{Y}_{\mathrm{p} / \mathrm{x}}\right)$ Product yield coefficient $(\mathrm{U} / \mathrm{g})$, the value of $\left(\mathrm{Y}_{\mathrm{p} / \mathrm{x}}\right)$ was determined by the equation:

(2) $Y_{p / x}=d p / d x$

- $\left(\mathrm{q}_{\mathrm{p}}\right)$ Specific product yield coefficient $(\mathrm{U} / \mathrm{g} / \mathrm{h})$, the value of $\left(\mathrm{q}_{\mathrm{p}}\right)$ was determined by the equation:

(3) $q_{p}=Y_{p / x} \times \mu_{\max }$

\section{RESULTS}

\section{Effect of incubation temperature}

Optimal production of $\alpha$-amylase in stirred fermenter was examined in different incubation temperatures from $30^{\circ} \mathrm{C}$ to $50^{\circ} \mathrm{C}$ with constant agitation speed of $100 \mathrm{rpm}$ and aeration rate of $0.5 \mathrm{vvm}$. Figure 1 shows the effect of temperature on cell growth and enzyme production by $B$. licheniformis-AZ2 at different time courses. As can be seen, cell growth and enzyme production were increased as the incubation temperature was elevated from $30^{\circ} \mathrm{C}$ and reached maximum at $37^{\circ} \mathrm{C}$ both in enzyme production $(13.30 \pm 0.5 \mathrm{U} / \mathrm{mL})$ and cell dry biomass $(7.87 \pm 0.24$ $\mathrm{mg} / \mathrm{mL}$ ). At higher incubation temperatures $\alpha$-amylase production by the cell was reduced significantly, which shows the inhibitory effect of higher temperatures on the growth of microorganism. Evaluation of kinetic parameters also revealed the same results as depicted in Figure 1. The product yield coefficient $\left(\mathrm{Y}_{\mathrm{p} / \mathrm{x}}\right)$, specific product yield coefficient $\left(\mathrm{q}_{\mathrm{p}}\right)$, the volumetric rate of product formation $\left(\mathrm{Q}_{\mathrm{p}}\right)$ and biomass formation $\left(\mathrm{Q}_{\mathrm{x}}\right)$ were all maximum at $37^{\circ} \mathrm{C}$ showing optimum temperature for $\alpha$-amylase production (Table 1). 
Table 1. Kinetic study of cell growth and $\alpha$-amylase production by B. licheniformis- $A Z 2$ at different incubation temperatures

\begin{tabular}{|cccccc|}
\hline $\begin{array}{c}\text { Incubation } \\
\text { Temperature }\left({ }^{\circ} \mathbf{C}\right)\end{array}$ & $\begin{array}{c}\mathbf{Q}_{\mathbf{x}}{ }^{1} \\
(\mathbf{g} / \mathbf{L} / \mathbf{h})\end{array}$ & $\begin{array}{c}\mathbf{Q}_{\mathbf{p}}{ }^{2} \\
(\mathbf{U} / \mathbf{L} / \mathbf{h})\end{array}$ & $\begin{array}{c}\mathbf{Y}_{\mathbf{p} / \mathbf{x}}{ }^{3} \\
(\mathbf{U} / \mathbf{g})\end{array}$ & $\begin{array}{c}\boldsymbol{\mu}_{\max }{ }^{4} \\
\left(\mathbf{h}^{-1}\right)\end{array}$ & $\begin{array}{c}\mathbf{q}_{\mathbf{p}}{ }^{5} \\
(\mathbf{U} / \mathbf{g} / \mathbf{h})\end{array}$ \\
\hline 30 & $0.21^{\mathrm{d}}$ & $356.0^{\mathrm{d}}$ & $14.09^{\mathrm{c}}$ & $0.085^{\mathrm{c}}$ & $1.20^{\mathrm{d}}$ \\
35 & $0.26^{\mathrm{c}}$ & $391.6^{\mathrm{c}}$ & $20.79^{\mathrm{c}}$ & $0.096^{\mathrm{ab}}$ & $2.01^{\mathrm{c}}$ \\
37 & $0.39^{\mathrm{a}}$ & $544.0^{\mathrm{a}}$ & $35.97^{\mathrm{a}}$ & $0.102^{\mathrm{a}}$ & $3.67^{\mathrm{a}}$ \\
40 & $0.31^{\mathrm{b}}$ & $503.3^{\mathrm{b}}$ & $32.78^{\mathrm{b}}$ & $0.101^{\mathrm{a}}$ & $3.31^{\mathrm{b}}$ \\
45 & $0.23^{\mathrm{d}}$ & $324.0^{\mathrm{d}}$ & $19.67^{\mathrm{d}}$ & $0.092^{\mathrm{b}}$ & $1.81^{\mathrm{c}}$ \\
50 & $0.22^{\mathrm{d}}$ & $267.3^{\mathrm{e}}$ & $13.97^{\mathrm{e}}$ & $0.092^{\mathrm{b}}$ & $1.29^{\mathrm{d}}$ \\
\hline
\end{tabular}

Kinetic parameters: ${ }^{1} Q_{x}=$ g cell mass formation $/ \mathrm{L} / \mathrm{h},{ }^{2} \mathrm{Q}_{\mathrm{p}}=$ Enzyme produced/L/h, ${ }^{3} Y_{p / x}=$ Enzyme produced/g cell mass formation, ${ }^{4} \mu_{\max }$ $\left(h^{-1}\right)=$ Specific growth rate, ${ }^{5} q_{p}=$ Product formation specific rate $U / g / h$. Means with different letters indicate significant differences between treatments $(P<0.05$, Duncan's multiple range test $)$

\section{Effect of aeration rate and agitation speed}

A basic requirement for a fermenter is the provision of aeration system that can maintain a high dissolved oxygen level for aerobic fermentation. In this connection different volume of air supply and rate of agitation speed were studied for the optimal enzyme production in stirred fermenter (Figure 2 and Figure 3).

The effect of aeration rate was investigated by comparing cell growth and enzyme production performances at aeration rates of $0,0.5,1,1.5,2$ and $2.5 \mathrm{vvm}$ with operating temperature and agitation speed maintained at $37^{\circ} \mathrm{C}$ and $100 \mathrm{rpm}$, respectively. As depicted in Figure 2, the minimum level of cell growth and enzyme production were achieved when there was no air supplying, which shows lack of aeration during the fermentation was an extremely important limiting factor for cell growth and metabolite formation, so that increasing in the aeration rate from 0 to $1 \mathrm{vvm}$ not only improved the cell growth but also enhanced the enzyme production level. As can be inferred from statistics, aeration (at $1 \mathrm{vvm}$ ) has also promoted drastic increases in the kinetic parameters of $B$. licheniformis-AZ2. Compared with no aeration fermentation, volumetric rates i.e. cell biomass formation and enzyme production were increased about 3.2 folds and 32 folds, while specific rate constants i.e. production yield coefficient $\left(\mathrm{Y}_{\mathrm{p} / \mathrm{x}}\right)$, and product formation specific rate $\left(\mathrm{q}_{\mathrm{p}}\right)$ showed a 1152-fold, and 2353-fold increase in their values, respectively (Table 2 ).

The maximum $\alpha$-amylase production $(17.66 \pm 0.87 \mathrm{U} /$ $\mathrm{mL})$, cell dry biomass $(8.94 \pm 0.25 \mathrm{mg} / \mathrm{mL})$ and fermentation kinetic parameters were obtained when the aeration rate fixed at $1 \mathrm{vvm}$ (Figure 2, Table 2). However, over aeration at $1 \mathrm{vvm}$ caused a significant reduction in the cell growth and enzyme production. Thus aeration rate of 1 vvm was selected for further studies. Afterward different agitation speeds of 50,100, 150, 200, 250 and $300 \mathrm{rpm}$ were examined on $\alpha$-amylase production at the constant temperature of $37^{\circ} \mathrm{C}$ and aeration rate of $1 \mathrm{vvm}$ (Figure 3 ).

The highest $\alpha$-amylase production $(17.66 \pm 0.87 \mathrm{U} /$ $\mathrm{mL} ; 16.45 \pm 0.95 \mathrm{U} / \mathrm{mL})$ and cell dry mass $(8.94 \pm 0.25$ $\mathrm{mg} / \mathrm{mL} ; 8.50 \pm 0.3 \mathrm{mg} / \mathrm{mL}$ ) without any significant differences were achieved at agitation speeds of $100 \mathrm{rpm}$ and $150 \mathrm{rpm}$, respectively. Whereas, beyond the optimal agitation speed range of $100 \mathrm{rpm}$ to $150 \mathrm{rpm}$, cell growth

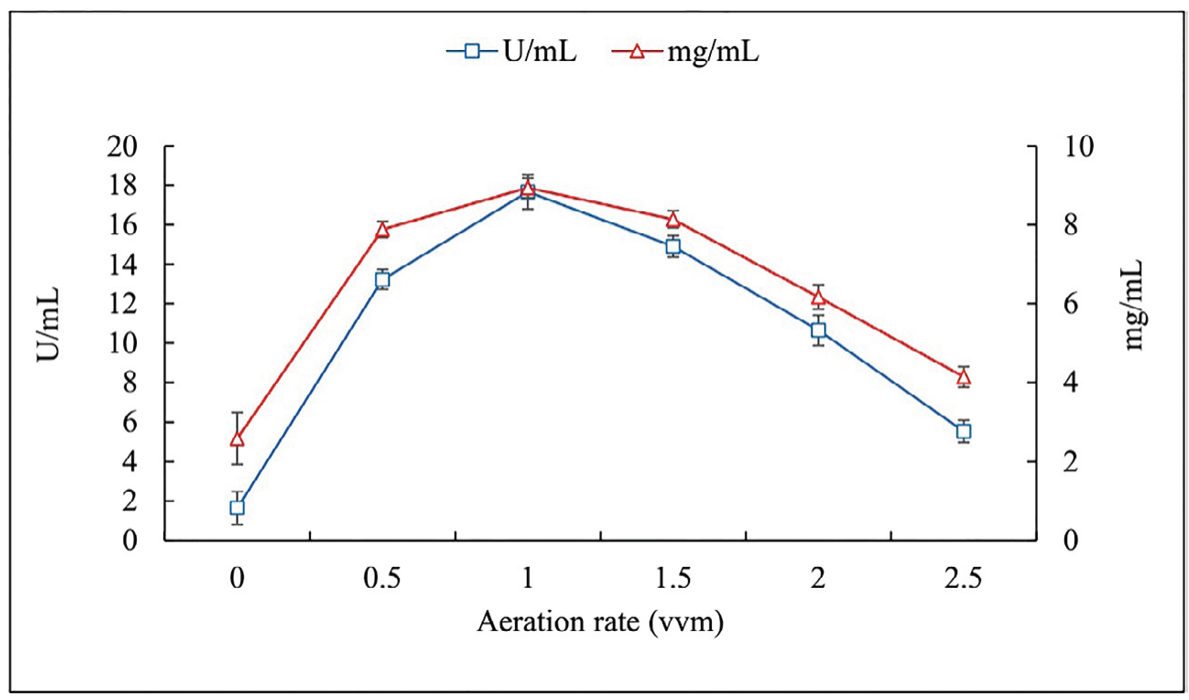

Figure 2. Effect of aeration rate on cell growth and production of $\alpha$-amylase by $\mathrm{B}$. licheniformis- $\mathrm{AZ2}$ at optimum temperature of $37^{\circ} \mathrm{C}$, $\mathrm{pH} 9.0$ and agitation speed of $100 \mathrm{rpm}$ after $60 \mathrm{~h}$.

Mean \pm S.E.M $=$ Mean values \pm Standard error of means of three replications. 
Table 2. Kinetic study of cell growth and $\alpha$-amylase production by $\mathrm{B}$. licheniformis- $A Z 2$ at different aeration rates

\begin{tabular}{|cccccc|}
\hline $\begin{array}{c}\text { Aeration } \\
\text { Rates (vvm) }\end{array}$ & $\begin{array}{c}\mathbf{Q}_{\mathbf{x}}{ }^{1} \\
(\mathbf{g} / \mathbf{L} / \mathbf{h})\end{array}$ & $\begin{array}{c}\mathbf{Q}_{\mathbf{p}}{ }^{2} \\
(\mathbf{U} / \mathbf{L} / \mathbf{h})\end{array}$ & $\begin{array}{c}\mathbf{Y}_{\mathbf{p} / \mathbf{x}}{ }^{3} \\
(\mathbf{U} / \mathbf{g})\end{array}$ & $\begin{array}{c}\boldsymbol{\mu}_{\max }{ }^{4} \\
\left(\mathbf{h}^{-1}\right)\end{array}$ & $\begin{array}{c}\mathbf{q}_{\mathbf{p}}{ }^{5} \\
(\mathbf{U} / \mathbf{g} / \mathbf{h})\end{array}$ \\
\hline 0 & $0.13^{\mathrm{d}}$ & $22.6^{\mathrm{d}}$ & $0.04^{\mathrm{f}}$ & $0.059^{\mathrm{d}}$ & $0.002^{\mathrm{f}}$ \\
0.5 & $0.39^{\mathrm{a}}$ & $544.0^{\mathrm{b}}$ & $35.97^{\mathrm{b}}$ & $0.102^{\mathrm{ab}}$ & $3.67^{\mathrm{b}}$ \\
1 & $0.40^{\mathrm{a}}$ & $723.1^{\mathrm{a}}$ & $45.17^{\mathrm{a}}$ & $0.120^{\mathrm{a}}$ & $5.41^{\mathrm{a}}$ \\
1.5 & $0.34^{\mathrm{b}}$ & $541.5^{\mathrm{b}}$ & $29.31^{\mathrm{c}}$ & $0.099^{\mathrm{b}}$ & $2.92^{\mathrm{c}}$ \\
2 & $0.22^{\mathrm{c}}$ & $420.6^{\mathrm{c}}$ & $18.02^{\mathrm{d}}$ & $0.094^{\mathrm{b}}$ & $1.69^{\mathrm{d}}$ \\
2.5 & $0.19^{\mathrm{cd}}$ & $138.6^{\mathrm{e}}$ & $6.31^{\mathrm{e}}$ & $0.078^{\mathrm{c}}$ & $0.55^{\mathrm{e}}$ \\
\hline
\end{tabular}

Kinetic parameters: ${ }^{1} \mathrm{Q}_{\mathrm{x}}=\mathrm{g}$ cell mass formation $/ \mathrm{L} / \mathrm{h},{ }^{2} \mathrm{Q}_{\mathrm{p}}=$ Enzyme produced/L/h, ${ }^{3} Y_{p / x}=$ Enzyme produced/g cell mass formation, ${ }^{4} \mu_{\max }$ $\left(h^{-1}\right)=$ Specific growth rate, ${ }^{5} \mathrm{q}_{\mathrm{p}}=$ Product formation specific rate U/g/h. Means with different letters indicate significant differences between treatments $(P<0.05$, Duncan's multiple range test).

and $\alpha$-amylase production were lowered significantly. This may be due to adverse effect of high shear stress on the living cells. At agitation speeds $\geq 200 \mathrm{rpm}$, excessive foaming occurred thus the foams were suppressed by addition of silicon antifoam reagent.

The values of $Y_{p / x}, q_{p}, Q_{p}$ and $Q_{x}$ obtained after kinetic analysis of results revealed that the best aeration and agitation for $\alpha$-amylase production were $1 \mathrm{vvm}$ and 100 rpm, respectively (Table 2 and Table 3). Our results show that adjustment of agitation speed and aeration rate could greatly improve gas-liquid transfer and mixing in the fermenter.
Table 3. Kinetic study of cell growth and $\alpha$-amylase production by $\mathrm{B}$. licheniformis- $A Z 2$ at different agitation speeds

\begin{tabular}{|cccccc|}
\hline $\begin{array}{c}\text { Agitation } \\
\text { Speed (rpm) }\end{array}$ & $\begin{array}{c}\mathbf{Q}_{\mathbf{x}}{ }^{1} \\
(\mathbf{g} / \mathbf{L} / \mathbf{h})\end{array}$ & $\begin{array}{c}\mathbf{Q}_{\mathbf{p}}{ }^{2} \\
(\mathbf{U} / \mathbf{L} / \mathbf{h})\end{array}$ & $\begin{array}{c}\mathbf{Y}_{\mathbf{p} / \mathbf{x}}{ }^{3} \\
(\mathbf{U} / \mathbf{g})\end{array}$ & $\begin{array}{c}\boldsymbol{\mu}_{\max }{ }^{4} \\
\left(\mathbf{h}^{-1}\right)\end{array}$ & $\begin{array}{c}\mathbf{q}_{\mathbf{p}}{ }^{5} \\
(\mathbf{U} / \mathbf{g} / \mathbf{h})\end{array}$ \\
\hline 50 & $0.37^{\mathrm{a}}$ & $639.3^{\mathrm{b}}$ & $38.33^{\mathrm{b}}$ & $0.110^{\mathrm{ab}}$ & $4.43^{\mathrm{ab}}$ \\
100 & $0.40^{\mathrm{a}}$ & $723.1^{\mathrm{a}}$ & $45.17^{\mathrm{a}}$ & $0.120^{\mathrm{a}}$ & $5.41^{\mathrm{a}}$ \\
150 & $0.39^{\mathrm{a}}$ & $713.5^{\mathrm{a}}$ & $41.67^{\mathrm{a}}$ & $0.114^{\mathrm{a}}$ & $4.79^{\mathrm{b}}$ \\
200 & $0.32^{\mathrm{b}}$ & $531.2^{\mathrm{c}}$ & $37.86^{\mathrm{b}}$ & $0.108^{\mathrm{ab}}$ & $4.10^{\mathrm{c}}$ \\
250 & $0.27^{\mathrm{c}}$ & $442.0^{\mathrm{d}}$ & $24.57^{\mathrm{c}}$ & $0.092^{\mathrm{b}}$ & $2.27^{\mathrm{d}}$ \\
300 & $0.26^{\mathrm{c}}$ & $387.8^{\mathrm{e}}$ & $16.66^{\mathrm{d}}$ & $0.082^{\mathrm{b}}$ & $1.36^{\mathrm{e}}$ \\
\hline
\end{tabular}

Kinetic parameters: ${ }^{1} \mathrm{Q}_{\mathrm{x}}=\mathrm{g}$ cell mass formation $/ \mathrm{L} / \mathrm{h},{ }^{2} \mathrm{Q}_{\mathrm{p}}=$ Enzyme produced/L/h, ${ }^{3} Y_{\mathrm{p} / \mathrm{x}}=$ Enzyme produced/g cell mass formation, ${ }^{4} \mu_{\max }$ $\left(h^{-1}\right)=$ Specific growth rate, ${ }^{5} \mathrm{q}_{\mathrm{p}}=$ Product formation specific rate $\mathrm{U} / \mathrm{g} / \mathrm{h}$. Means with different letters indicate significant differences between treatments $(P<0.05$, Duncan's multiple range test).

\section{Kinetics of cell growth and fermentation pattern of $\alpha$-amylase in shake flasks and stirred fermenter under batch conditions}

Figure 4 shows changes in dry cell biomass and $\alpha$-amylase activity as a function of fermentation time in the shake flask and stirred fermenter. As shown, in the shake flask exponential growth began after a prolonged lag phase of $42 \mathrm{~h}$ and continued for $18 \mathrm{~h}$ until reaching stationary phase. The highest $\alpha$-amylase production of $8.67 \pm 0.5 \mathrm{U} /$ $\mathrm{mL}$ and cell dry mass $6.41 \pm 0.16 \mathrm{mg} / \mathrm{mL}$ were obtained in shake flask culture during the late stationary phase of growth after about $120 \mathrm{~h}$. In contrast, in the stirred fer-

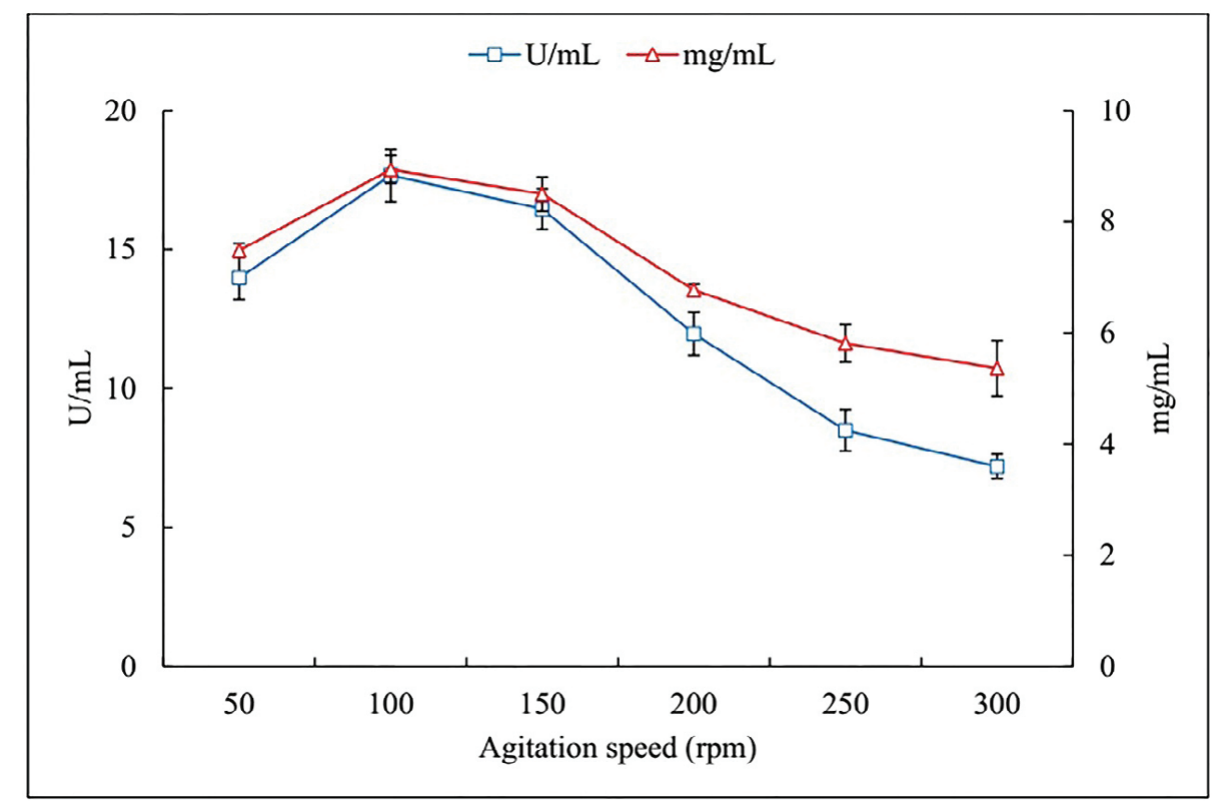

Figure 3. Effect of agitation speed on cell growth and production of $\alpha$-amylase by $\mathrm{B}$. licheniformis- $A Z 2$ at optimum temperature of $37^{\circ} \mathrm{C}$, $p H$ 9.0 and aeration rate of $1 \mathrm{vvm}$ after $60 \mathrm{~h}$.

Mean \pm S.E.M $=$ Mean values \pm Standard error of means of three replications. 


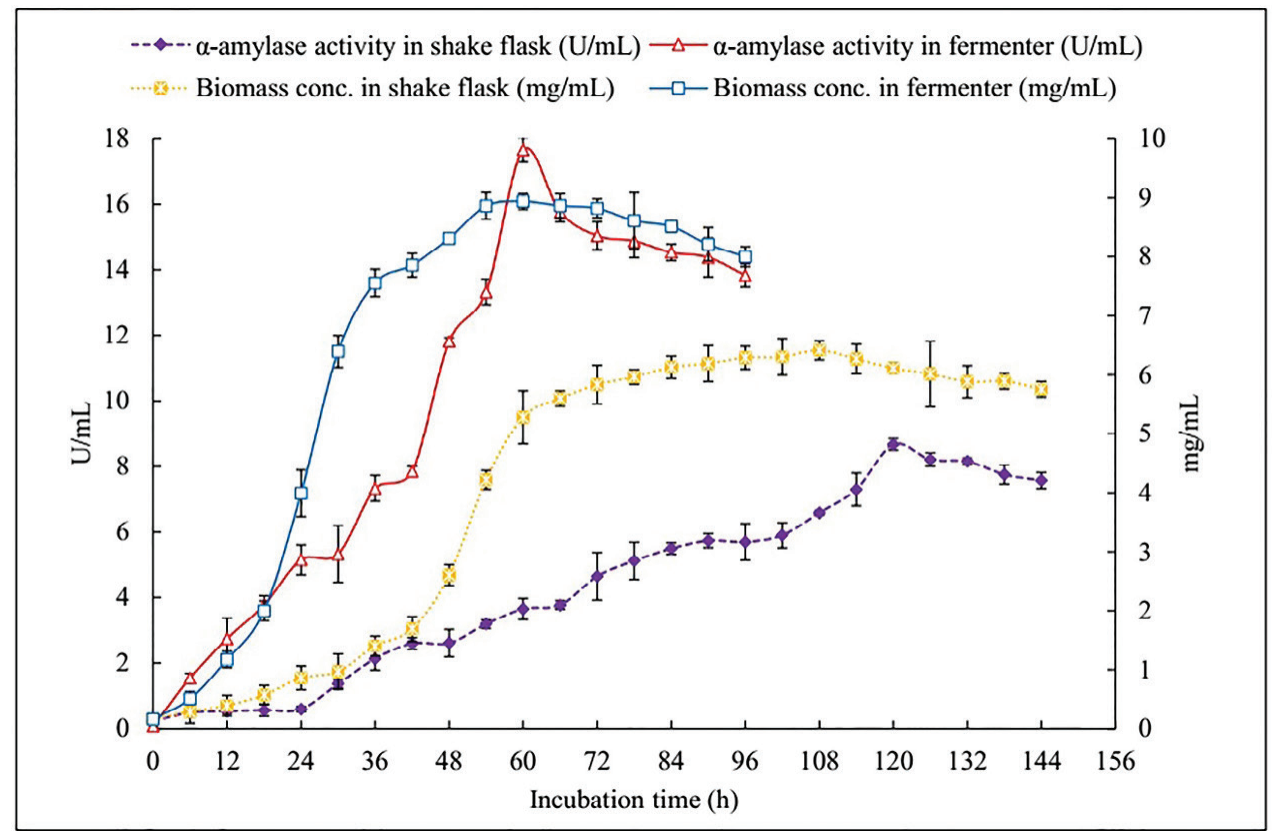

Figure 4. Fermentation profile of $\mathrm{B}$. licheniformis-AZ2. $\alpha$-amylase produced under optimum fermentation condition using a fermenter and shake flasks. The temperature of fermenter was controlled at $37^{\circ} \mathrm{C}, \mathrm{pH} 9.0$, aeration rate of $1 \mathrm{vvm}$ and agitation speed of $100 \mathrm{rpm}$. Shaken cultures were incubated at $40^{\circ} \mathrm{C}$, initial pH 9.0 on a rotary shaker at fixed agitation speed of $120 \mathrm{rpm}$.

Mean \pm S.E.M $=$ Mean values \pm Standard error of means of three replications.

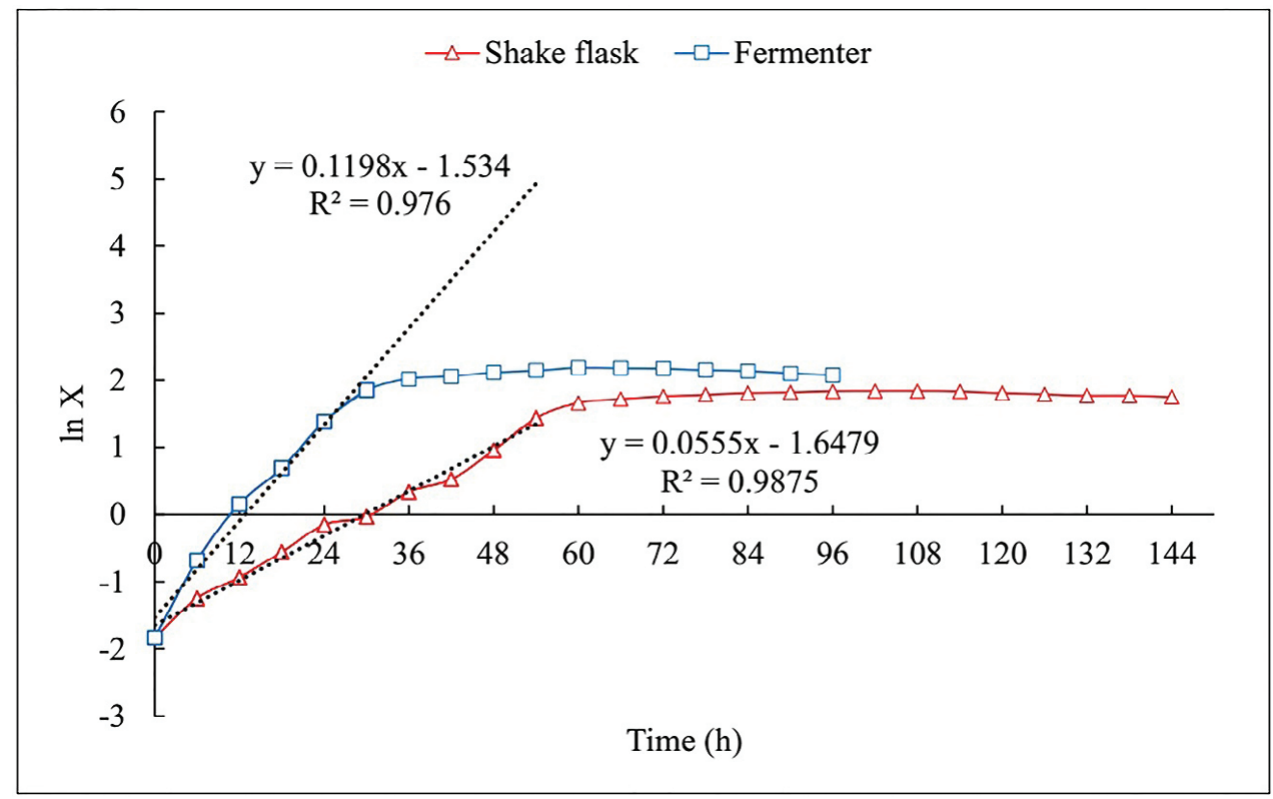

Figure 5. Specific growth rates of $\mathrm{B}$. licheniformis-AZ2 incubated for various fermentation time under optimum fermentation conditions using stirred fermenter and shake flask.

menter cells grew exponentially after about $12 \mathrm{~h}$ of lag phase and reached to the stationary phase of growth by dry cell biomass of about $8.94 \pm 0.25 \mathrm{mg} / \mathrm{mL}$ after $42 \mathrm{~h}$. Peak $\alpha$-amylase activity $(17.66 \pm 0.87 \mathrm{U} / \mathrm{mL})$ in the stirred fermenter was observed in the mid stationary phase of growth after $60 \mathrm{~h}$ of fermentation time. This time was 60 hours shorter than the corresponding batch culture in the shake flask. In the stirred fermenter, the fermentation was much faster than that in the shake flask, as indicated by biomass formation rates (Figure 4). This may be ascribed to improved aeration and mass transfer in the stirred fermenter. The natural $\log$ of biomass ( $\ln \mathrm{X}$ ) against fermentation 
Table 4. Kinetic study of cell growth and $\alpha$-amylase production by B. licheniformis-AZ2 under optimal fermentation conditions using stirred fermenter and shake flask

\begin{tabular}{|c|c|c|c|c|c|c|}
\hline $\begin{array}{c}\text { Fermentation } \\
\text { condition }\end{array}$ & $\begin{array}{c}Q_{\mathrm{x}}{ }^{1} \\
(\mathrm{~g} / \mathrm{L} / \mathrm{h})\end{array}$ & $\begin{array}{c}\mathbf{Q}_{\mathrm{p}}{ }^{2} \\
(\mathbf{U} / \mathbf{L} / \mathbf{h})\end{array}$ & $\begin{array}{l}Y_{p / x}{ }^{3} \\
(\mathbf{U} / g)\end{array}$ & $\begin{array}{c}\boldsymbol{\mu}_{\max } \\
\left(\mathbf{h}^{-1}\right)\end{array}$ & $\begin{array}{c}\mathbf{q}_{p}{ }^{5} \\
(\mathbf{U} / \mathbf{g} / \mathbf{h})\end{array}$ & $\begin{array}{l}t_{d}{ }^{6} \\
(h)\end{array}$ \\
\hline $\begin{array}{l}\text { Stirred Fer- } \\
\text { menter }\end{array}$ & $0.40^{\mathrm{a}}$ & $723.1^{a}$ & $45.17^{\mathrm{a}}$ & $0.120^{\mathrm{a}}$ & $5.41^{a}$ & $5.78^{\mathrm{b}}$ \\
\hline Shake flask & $0.27^{b}$ & $228.6^{\mathrm{b}}$ & $13.64^{b}$ & $0.055^{\mathrm{b}}$ & $0.76^{\mathrm{b}}$ & $12.48^{\mathrm{a}}$ \\
\hline
\end{tabular}

Kinetic parameters: ${ }^{1} Q_{x}=g$ cell mass formation $/ \mathrm{L} / \mathrm{h},{ }^{2} \mathrm{Q}_{\mathrm{p}}=$ Enzyme produced/L/h, ${ }^{3} \mathrm{Y}_{\mathrm{p} / \mathrm{x}}=$ Enzyme produced/g cell mass formation, ${ }^{4} \mu_{\max }$ $\left(h^{-1}\right)=$ Specific growth rate, ${ }^{5} \mathrm{q}_{\mathrm{p}}=$ Product formation specific rate $\mathrm{U} / \mathrm{g} / \mathrm{h}$, ${ }^{6} t_{d}=$ Generation time (h).

Means with different letters indicate significant differences between treatments $(P<0.05$, Duncan's multiple range test $)$.

time was plotted for both shake flask and the stirred fermenter (Figure 5). In the stirred fermenter, no significant lag observed in the growth, most probably due to the optimal aeration and agitation. In the stirred fermenter, during the first $30 \mathrm{~h}$, the specific growth rate was $0.1198 \mathrm{~h}^{-1}$, and it gradually decreased in the next $6 \mathrm{~h}$. This indicates that the true logarithmic growth phase lasted for the first $30 \mathrm{~h}$. However, in shake flask, logarithmic growth was observed for the first $60 \mathrm{~h}$, during which the specific growth rate remained at $0.0555 \mathrm{~h}^{-1}$, afterwards, it gradually decreased, showing termination of the exponential growth phase. The generation times $\left(t_{d}\right)$ during the exponential phases were calculated to be $5.78 \mathrm{~h}$ and $12.48 \mathrm{~h}$ in the stirred fermenter and shake flask, respectively.

\section{DISCUSSION}

The genus Bacillus has the capacity to produce a wide variety of extracellular enzymes with broad ranges of application, among them amylases particularly have considerable industrial importance (31). Up scaling the fermentation processes from laboratory to commercial scales is always a challenging problem, because it is difficult to assess the impact of factors influencing the scale-up bioprocess during the fermentation (32). It is well known that production of extracellular industrial enzymes by microorganisms in fermenters is greatly affected by media components and different physical factors (33). Therefore, studying the effect of operational conditions such as incubation temperature, agitation speed and aeration rate on enzyme production might provide more reliable and comprehensive understanding about the enzyme synthesis patterns, other environmental requirements, influential parameters, and information about process scale-up (34).

As synthesis of $\alpha$-amylase correlated with bacterial growth, an improvement on bacterial growth environment would enhance $\alpha$-amylase synthesis. It has long been established that temperature plays an important role in growth of bacteria and activity of their enzymes in fermentation medium (35). In this study, $\alpha$-amylase pro- duction and growth of $B$. licheniformis-AZ2 were found to be optimal at $37^{\circ} \mathrm{C}$. Similar results for growth and $\alpha$ amylase production were reported for $B$. licheniformis ATCC 6346 (17) and B. amyloliquefaciens EMS-6 (36). However, temperature optima beyond $37^{\circ} \mathrm{C}$ were also reported in literatures for B. licheniformis BT5.9 (37) and B. licheniformis (38).

On the other hand, it has been demonstrated by Mamo and Gessesse (39) increasing the incubation temperature in B. stearothermophilus cultures would be accompanied by the decreased level of cell-free amylases and concomitantly a rise in the amount of cell-bound amylases so that total (cell-free and cell-bound) amylase activity at different temperature values remains almost stable. It has been suggested that such differences in the level of amylase activity may not be due to the direct effect of temperature on bacterial growth. Therefore, the other possible explanation could be that the level of cell-free amylase released into the fermentation medium might be indirectly affected by temperature. In bacterial cells, releasing extracellular enzymes into fermentation medium is strictly controlled by several mechanisms. One of these mechanisms which can be induced by temperature is the changes made in the nature of cell envelope (cell membrane and cell wall) $(26,39,40)$.

In Bacilli, it is also believed that the S-layer (surface protein layer) is affected by changes in oxygen levels in fermentation medium, which is associated with control of the extracellular enzymes secretion (41-43). Thus, temperature through changing the level of dissolved oxygen in fermentation medium could indirectly affect the conformation of cell wall and S-layer, which thereupon leads to different temperature optima for growth and enzyme production (39). Accordingly, releasing of $\alpha$-amylase by $B$. licheniformis-AZ2 cells might have reduced at elevated temperatures $\left(40^{\circ} \mathrm{C}, 45^{\circ} \mathrm{C}\right.$ and $50^{\circ} \mathrm{C}$ ) due to the poor solubility of oxygen and high rate of oxygen consumption (Figure 1).

Unlike most other Bacilli which are typically aerobic, $B$. licheniformis is known to be a facultative anaerobic which may afford it to grow in more ecological niches (44). However, the production of $\alpha$-amylase by $B$. licheniformis is generally accepted as an aerobic process (26). Therefore, in order to fulfil the requirements of microorganism for high oxygen needs fermentation medium must be continuously supplied with gaseous oxygen. Otherwise, the oxygen transfer can become a major limiting factor for cell growth and metabolism (45).

The cell biomass values also varied with changes in aeration rates and maximum cell biomass and $\alpha$-amylase production appeared at optimal value of $1 \mathrm{vvm}$ (Figure 2). This indicates that increase in aeration rates would yield a higher cell biomass. However, a decrease in cell biomass and $\alpha$-amylase production was noted at $\geq 1.5$ vvm aeration rates that might ascribe to inappropriate transfer rate of oxygen in the fermentation medium. Re- 
cently a phenomenon called "impeller flooding" has been reported in some studies, in which the air stream up in the bioreactor increased along the stirrer shaft when higher aeration flows was accompanied by lower agitation speeds. In this case, a column of air surrounds the impeller, and there will no longer be a proper contact with the liquid in the vessel, which results in reduced air dispersion, poor mixing and diminished oxygen transfer rates. This phenomenon has been recommended to be avoided by finding an appropriate combination of aeration rate and agitation speed together (46).

The optimal agitation speed for $\alpha$-amylase production was determined to be in the range of 100-150 rpm, while increasing in agitation speed beyond $150 \mathrm{rpm}$ significantly reduced the cell growth and enzyme production yield followed by foam formation in fermenter (Figure 3). It has been demonstrated that exerting higher agitation speeds using mechanical stirrers damage microbial cells through imposing high sheer stress, on the contrary, lower agitation speeds could cause improper mixing of nutrients which ultimately affect $\alpha$-amylase yield in both cases (47). All these efforts indicate that there should be a balance between aeration rate and agitation speed for the optimum yield of cell biomass and $\alpha$-amylase production.

As it mentioned by Hessleink (48), the catalytic activity of an organism will not be fully accomplished unless adequate levels of oxygen are constantly supplied in close proximity of the cells through aeration and agitation. Adversely, higher agitation speeds by induction of shearing forces and vortex formation in fermentation broth could also cause an impaired mass transfer rate and therefore reduced enzyme secretion. Current study also pointed out that higher agitation speeds can cause a drastic reduction in extracellular enzyme production by $B$. licheniformisAZ2 (Figure 3).

As it can be deduced from Figure 4, the lag phase was significantly shortened after scaling up the fermentation process from shake flask to stirred fermenter in batch mode. In shaken cultures, the lag phase and acceleration of cell growth was elongated by approximately $42 \mathrm{~h}$. While in stirred fermenter this time was much faster and after taking only about $16 \mathrm{~h}$ of incubation cells entered to logarithmic phase, which resulted in a shorter incubation time in stirred fermenter condition. The longer fermentation process in shake flask cultures was probably due to the limited oxygen uptake and gas exchange, because shake flasks are usually agitated at a fixed speed and most cultures are doomed to failure when the available ambient oxygen is depleted from the surroundings. Other limiting factors in batch shaken cultures could be lack of $\mathrm{pH}$ control and imprecise control of temperature (49).

In general, the prolonged lag phase observed in this study in comparison of other studies with simple sugars as energy source might be due to the type of carbon source. It has been proven that the composition of agri- cultural residues used in fermentation medium by affecting the length of the lag phase and primary metabolism could alter the time needed by microorganism for enzyme synthesis. Madar et al. (50) also stated that there is a programmed evolutionary gene expression during the lag phase for synthesis of crucial enzymes based on type of available carbon sources in fermentation medium, which helps microorganism with the best exploitation of biomass once exits from the lag phase. Therefore, simple carbon sources compel the organism to rapidly enter to long logphase, leading to the formation of more dry cell biomass, while more complex carbon sources like agro-wastes cause a delay in the commencement of log-phase and increase in generation time.

The bacterial cells subsequently entered in exponential phase of growth with generation times of $12.48 \mathrm{~h}$ and $5.78 \mathrm{~h}$ in stirred fermenter and shake flask cultures, respectively. During the exponential phase of growth $\alpha$ amylase production increased with increase in cell biomass which found to be growth-associated. There are some contradictory reports in literatures regarding the phase of growth in which Bacillus species show their maximal $\alpha$-amylase production. As some reports have suggested that the highest enzyme activity is obtained in the exponential phase of growth, whereas some other indicated that it occurs at the mid-stationary phase (51). In the present study the highest levels of $\alpha$-amylase production by $B$. licheniformis-AZ2 in both the shake flask and the stirred fermenter were observed at the stationary phase of bacterial growth (Figure 4).

The constant cell biomass yield of bacteria during the post-logarithmic (deceleration) and stationary phases suggests that substrate has been efficiently consumed by microorganism until stationary phase. This fact implies that enzyme production is not absolutely growth dependent and forceful induction of $\alpha$-amylase may not occur unless the stationary phase of growth has been reached and readily available carbon sources were depleted from the fermentation medium (52). Ultimately, after about $72 \mathrm{~h}$ and $114 \mathrm{~h}$ of process time in stirred fermenter and shake flask conditions, cell death dominated, which directly corresponds to secondary nutrient depletion and accumulation of toxic metabolite products (53).

\section{CONCLUSION}

In our previous study, among the strains isolated from Qinarje Hot Spring B. licheniformis-AZ2 has been found as an appropriate strain for $\alpha$-amylase production. We have also conducted optimization experiments in order to enhance $\alpha$-amylase production in shake flask level and ultimately a low-cost fermentation medium containing rice husk was developed. In this study we have attempted to scale up enzyme production from $100 \mathrm{~mL}$ in shake flask to $1 \mathrm{~L}$ under stirred fermenter condition. Finding of the present study indicates a 2.1 -fold increase in $\alpha$-amylase 
production under stirred fermenter condition with optimized agitation speed of $100 \mathrm{rpm}$ and $1 \mathrm{vvm}$ aeration rate at $37^{\circ} \mathrm{C}$ in a 60 -hour-shorter process time compare to the shake flask experiments. Kinetic fermentation parameters also confirm the superiority of fermenter cultures. To be commercialized further studies are needed for scaling up in pilot-scale before testing larger samples in production scale. The enzyme production will have to be carried out in fed batch fermentation system in future.

Acknowledgments: Authors greatly appreciate research facilities and financial supports from Bu-Ali Sina University for conducting this research paper.

Conflicts of Interest: The authors declare no conflict of interest.

\section{REFERENCES}

1. ZURIDAH H, NORAZWIN N, SITI AISYAH M, FAKHRUZZAMAN M, ZEENATHUL N 2011 Identification of lipase producing thermophilic bacteria from Malaysian Hot Springs. Afr J Microbiol Res 5: 3569-3573. https://doi.org/10.5897/AJMR11.777

2. AANNIZ T, OUADGHIRI M, MELLOUL M, SWINGS J, ELFAHIME E, IBIJBIJEN J, ISMAILI M, AMAR M 2015 Thermophilic bacteria in Moroccan Hot Springs, salt marshes and desert soils. Braz J Microbiol 46: 443-453.

https://doi.org/10.1590/S1517-838246220140219

3. BORA L, GOHAIN D, DAS R 2013 Recent advances in production and biotechnological applications of thermostable and alkaline bacterial lipases. J Chem Technol Biotechnol 88: 1959-1970. https://doi.org/10.1002/jctb. 4170

4. SARMIENTO F, PERALTA R, BLAMEY JM 2015 Cold and hot extremozymes: industrial relevance and current trends. Front Bioeng Biotechnol 3: 1-15.

https://doi.org/10.3389/fbioe.2015.00148

5. MOBINI-DEHKORDI M, JAVAN FA 2012 Application of alphaamylase in biotechnology. J Biol Today's World 1: 15-20.

https://doi.org/10.15412/J.JBTW.01010104

6. DE OLIVEIRA APA, SILVESTRE MA, ALVES-PRADO HF, RODRIGUES A, DA PAZ MF, FONSECA GG, LEITE RSR 2015 Bioprospecting of yeasts for amylase production in solid state fermentation and evaluation of the catalytic properties of enzymatic extracts. Afr J Biotechnol 14: 1215-1223.

https://doi.org/10.5897/AJB2014.14062

7. TIWARI S, SRIVASTAVA R, SINGH C, SHUKLA K, SINGH R, SINGH P, SINGH R, SINGH N, SHARMA R 2015 Amylases: An overview with special reference to alpha amylase. J Global Biosci 4: 1886-1901

8. BRAYER GD, LUO Y, WITHERS SG 1995 The structure of human pancreatic $\alpha$-amylase at $1.8 \AA$ resolution and comparisons with related enzymes. Protein Sci 4: 1730-1742. https://doi.org/10.1002/pro.5560040908

9. ADMASSU H, ZHAO W, YANG R, GASMALLA MA, ZHANG W 2015 Recent advances on efficient methods for $\alpha$-amylase production by solid state fermentation (SSF). Int J Adv Res 3: 14851493

10. GUPTA R, GIGRAS P, MOHAPATRA H, GOSWAMI VK, CHAUHAN B 2003 Microbial $\alpha$-amylases: A biotechnological perspective. Process Biochem 38: 1599-1616.

https://doi.org/10.1016/S0032-9592(03)00053-0
11. BIELECKI S, POLAK J, TRAMPER J 2000 Food Biotechnology. Elsevier Science, Amsterdam, p 427

12. NAIDU M 2013 Bacterial amylase: A review. Int J Pharm Biol Arch 4: 274-287

13. DE SOUZA PM 2010 Application of microbial $\alpha$-amylase in industry-A review. Braz J Microbiol 41: 850-861. https://doi.org/10.1590/S1517-83822010000400004

14. PANDEY A, WEBB C, FERNANDES M, LARROCHE C 2006 Enzyme Technology. Springer Science \& Business Media, New York, p 742

15. GANGADHARAN D, NAMPOOTHIRI KM, PANDEY A $2011 \alpha$-Amylase production by Bacillus amyloliquefaciens using agro wastes as feed stock. Food Technol Biotechnol 49: 336-340

16. SIVARAMAKRISHNAN $S$, GANGADHARAN D, NAMPOOTHIRI KM, SOCCOL CR, PANDEY A $2006 \alpha$-Amylases from microbial sources-An overview on recent developments. Food Technol Biotechnol 44: 173-184

17. VENGADARAMANA A, BALAKUMAR S, ARASARATNAM V 2012 Production and optimization of $\alpha$-amylase by Bacillus $l i$ cheniformis ATCC6346 in lab Bench-Scale fermenter. J Microbiol Biotechnol Res 2: 190-211

18. DWORSCHACK RG, LAGODA AA, JACKSON RW 1954 Fermentor for small-scale submerged fermentations. Appl Microbiol 2: $190-197$

19. CHANDRASHEKHAR H, RAO JV 2010 An overview of fermenter and the design considerations to enhance its productivity. Pharmacologyonline 1: 261-301

20. THIRY M, CINGOLANI D 2002 Optimizing scale-up fermentation processes. Trends Biotechnol 20: 103-105. https://doi.org/10.1016/S0167-7799(02)01913-3

21. SOCCOL CR, PANDEY A, LARROCHE C 2013 Fermentation Processes Engineering in the Food Industry. CRC Press, Tylor \& Francis Group, Florida, p 510

22. WANG J, SHIH J 1999 Fermentation production of keratinase from Bacillus licheniformis PWD-1 and a recombinant B. subtilis FDB-29. J Ind Microbiol Biotechnol 22: 608-616. https://doi.org/10.1038/sj.jim.2900667

23. OCAMPO L, EZQUERRA JM 2002 Digestive protease activity in juvenile Farfantepenaeus californiensis as a function of dissolved oxygen and temperature. Aquac Res 33: 1073-1080. https://doi.org/10.1046/j.1365-2109.2002.00780.x

24. BANDAIPHET C, PRASERTSAN P 2006 Effect of aeration and agitation rates and scale-up on oxygen transfer coefficient, $\mathrm{k}_{\mathrm{L}} \mathrm{a}$ in exopolysaccharide production from Enterobacter cloacae WD7. Carbohydr Polym 66: 216-228.

https://doi.org/10.1016/j.carbpol.2006.03.004

25. RAIMBAULT M 1998 General and microbiological aspects of solid substrate fermentation. Elec J Biotechnol 1: 26-27. https://doi.org/10.2225/vol1-issue3-fulltext-9

26. TONKOVA A, MANOLOV R, DOBREVA E 1993 Thermostable $\alpha$-amylase from derepressed Bacillus licheniformis produced in high yields from glucose. Process Biochem 28: 539-542. https://doi.org/10.1016/0032-9592(93)85015-8

27. DLJOU A, AREZI I 2016 Production of thermostable extracellular $\alpha$-amylase by a moderate thermophilic Bacillus licheniformis isolated from Qinarje Hot Spring (Ardebil Prov. of Iran). Period Biol 118: 405-416. https://doi.org/10.18054/pb.v118i4.3737

28. RICK W, STEGBAUER H $1974 \alpha$-Amylase measurement of reducing groups. In: Bergermeyer HU (ed) Methods of Enzymatic Analysis. Verlag Chemie, Weinheim, pp 885-915

29. PIRT S 1975 Principles of Cell and Microbe Cultivation. Blackwells Scientific, New York, p 274

30. LAWFORD H, ROSEAU J 1993 Mannose fermentation by ethanologenic recombinants of $E$. coli and kinetical aspects. Biotechnol Lett 15: 615-620. https://doi.org/10.1007/BF00138551 
31. SWAIN MR, KAR S, PADMAJA G, RAY RC 2006 Partial characterization and optimization of production of extracellular alphaamylase from Bacillus subtilis isolated from culturable cow dung microflora. Pol J Microbiol 55: 289-96

32. HSU YL, WU WT 2002 A novel approach for scaling-up a fermentation system. Biochem Eng J 11: 123-130. https://doi.org/10.1016/S1369-703X(02)00016-5

33. GUPTA R, BEG Q, LORENZ P 2002 Bacterial alkaline proteases: molecular approaches and industrial applications. Appl Microbiol Biotechnol 59: 15-32. https://doi.org/10.1007/s00253002-0975-y

34. FENG Y, HE Z, ONG SL, HU J, ZHANG Z, NG WJ 2003 Optimization of agitation, aeration, and temperature conditions for maximum $\beta$-mannanase production. Enzyme Microb Technol 32: 282-289. https://doi.org/10.1016/S0141-0229(02)00287-9

35. KRAFT AA 1992 Psychotropic Bacteria in Foods: Disease and Spoilage. CRC Press Tylor \& Francis Group, Florida, p 288

36. HAQ I, ALI S, JAVED M, HAMEED U, SALEEM A, ADNAN F, QADEER M 2010 Production of alpha amylase from a randomly induced mutant strain of Bacillus amyloliquefaciens and its application as a desizer in textile industry. Pak J Bot 42: 473-484

37. IBRAHIM D, ZHU HL, YUSOF N 2013 Bacillus licheniformis BT5.9 isolated from Changar Hot Spring, Malang, Indonesia, as a potential producer of thermostable $\alpha$-amylase. Trop Life Sci Res 24: 71-84

38. AHMED AA, IBRAHIM HM 2011 A potential new isolate for the production of a thermostable extracellular $\alpha$-amylase. J Bacteriol Res 3: 129-137.

39. MAMO G, GESSESSE A 1999 Effect of cultivation conditions on growth and $\alpha$-amylase production by a thermophilic Bacillus sp. Lett Appl Microbiol 29: 61-65.

https://doi.org/10.1046/j.1365-2672.1999.00577.x

40. WIND R, BUITELAAR R, EGGINK G, HUIZING H, DIJKHUIZEN L 1994 Characterization of a new Bacillus stearothermophilus isolate: a highly thermostable $\alpha$-amylase-producing strain. Appl Microbiol Biotechnol 41: 155-162. https://doi.org/10.1007/BF00186953

41. EGELSEER EM, SCHOCHER I, SÁRA M, SLEYTR UB 1995 The S-layer from Bacillus stearothermophilus DSM2358 functions as an adhesion site for a high-molecular-weight amylase. J Bacteriol 177: 1444-1451. https://doi.org/10.1128/jb.177.6.14441451.1995

42. EGELSEER EM, SCHOCHER I, SLEYTR UB, SÁRA M 1996 Evidence that an $\mathrm{N}$-terminal S-layer protein fragment triggers the release of a cell-associated high-molecular-weight amylase in Bacillus stearothermophilus ATCC12980. J Bacteriol 178: 5602-5609. https://doi.org/10.1128/jb.178.19.5602-5609.1996

43. SÁRA M, KUEN B, MAYER HF, MANDL F, SCHUSTER KC, SLEYTR UB 1996 Dynamics in oxygen-induced changes in Slayer protein synthesis from Bacillus stearothermophilus PV72 and the S-layer-deficient variant T5 in continuous culture and studies of the cell wall composition. J Bacteriol 178: 2108-2117. https://doi.org/10.1128/jb.178.7.2108-2117.1996

44. REY MW, RAMAIYA P, NELSON BA, BRODY-KARPIN SD, ZARETSKY EJ, TANG M, DE LEON AL, XIANG H, GUSTI V, CLAUSEN IG 2004 Complete genome sequence of the industrial bacterium Bacillus licheniformis and comparisons with closely related Bacillus species. Genome Biol 5: R77. https://doi.org/10.1186/gb-2004-5-10-r77

45. LEE JM 1992 Biochemical Engineering. Prentice-Hall, Inc., Englewood Cliffs, New Jersy, p 336

46. DORAN PM 1995 Bioprocess Engineering Principles. Elsevier Science \& Technology Books, London, p 926

47. NADEEM M, QAZI JI, BAIG S 2009 Effect of aeration and agitation rates on alkaline protease production by Bacillus licheniformis UV-9 mutant. Turk J Biochem 34: 89-96. https://doi.org/10.1016/j.carbpol.2006.03.004

48. HESSLEINK P 1992 Oxygen and Gas-Liquid Mass Transfer in Operational Modes of Bioreactors. Biotechnology by Open Learning, BIOL Series, Butterworths/Heinemann, Oxford, p 344

49. OBOM KM, MAGNO A, CUMMINGS PJ 2013 Operation of a benchtop bioreactor. J Vis Exp 79: 50582. https://doi.org/10.3791/50582

50. MADAR D, DEKEL E, BREN A, ZIMMER A, PORAT Z, ALON U 2013 Promoter activity dynamics in the lag phase of Escherichia coli. BMC Syst Biol 7: 1-13. https://doi.org/10.1186/1752-0509-7-136

51. HUANG H, RIDGWAY D, GU T, MOO-YOUNG M 2003 A segregated model for heterologous amylase production by Bacillus subtilis. Enzyme Microb Technol 32: 407-413. https://doi.org/10.1016/S0141-0229(02)00312-5

52. WANDERLEY KJ, TORRES FA, MORAES LM, ULHOA CJ 2004 Biochemical characterization of $\alpha$-amylase from the yeast Cryptococcus flavus. FEMS Microbiol Lett 231: 165-169. https://doi.org/10.1016/S0378-1097(03)00955-8

53. JUŠKA A 2015 Analysis of Biological Processes: Verbal Description, Schemes, and Mathematical Models. Springer, Dordrecht, $\mathrm{p}$ 250. https://doi.org/10.1007/978-94-017-7373-7 